\title{
Comprehensive skin care with cosmetic preparations, dietary supplements and functional food
}

\author{
Kompleksowa pielegnacja skóry za pomoca preparatów \\ kosmetycznych, suplementów diety i żyuności funkcjonalnej
}

\begin{abstract}
Diet and consumption of appropriate quality food products are one of the most important elements for good health and condition of the whole organism, including a proper appearance and healthy skin. The condition of the body and the skin is also influenced by additional dietary supplements, synthetic multi-ingredient preparations, especially the ones containing ingredients selected for their beneficial effects on the skin.

The aim of the study was to describe the influence of dietary supplementation and the functional food for the condition of the skin, including preparations containing various nutrients and special-purpose food, which can have a beneficial effect on the skin and its healthy appearance.

The scope of the work includes a review of literature and sources in the field of dietetics and cosmetology.
\end{abstract}

Keywords: dietary supplements, functional food, healthy skin, nutricosmetics

\section{STRESZCZENIE}

Dieta i spożywanie odpowiedniej jakości produktów żywnościowych to jedne z najważniejszych elementów decydujących o dobrym zdrowiu organizmu człowieka, w tym o właściwym wyglądzie i zdrowej skórze. Na stan całego ustroju wpływają także spożywane dodatkowo różnorodne suplementy diety, syntetyczne preparaty wieloskładnikowe, preparaty specjalnie wzbogacone - zawierające składniki dobrane pod kątem korzystnego działania na skórę.

Celem pracy było opisanie wpływu suplementacji diety i tzw. żywności funkcjonalnej na stan skóry. Uwzględniono zażywane dodatkowo, oprócz podstawowych produktów odżywczych i poza odżywianiem w zakresie podstawowym i zbilansowaną dietą, preparaty zawierające różnorodne składniki odżywcze oraz żywność specjalnego przeznaczenia czyli funkcjonalną. Mogą one korzystnie wpływać na skórę i jej zdrowy wygląd.

Praca obejmuje przegląd tematycznej literatury i źródeł branżowych z obszaru dietetyki i kosmetologii.

Słowa kluczowe: suplementy diety, żywność funkcjonalna, zdrowa skóra, nutrikosmetyki

\section{INTRODUCTION}

The skin is the largest and one of the most important organs of the human body, and its condition is determined by many factors. Besides cosmetic care, involving various cosmetic preparations, ranging from cleansing, leading to the maintenance of proper skin hygiene, or protective, aimed at sustaining proper hydration and lubrication of the skin, it is vital to provide the body with appropriate nutrients, necessary for the proper development of skin cells. There are many different types of dietary protocols: food products, meals, dishes, special diets, so-called nutritional "thera- 
pies" that are dedicated to specific "problematic" cases and the coordination of the proper nutrition process. The additionally consumed, appropriately selected and properly dosed synthetic preparations and deliberately enriched food products containing ingredients that have a beneficial effect on the skin may also play a supporting role in this procedure. These kinds of products are known as nutricosmetics and functional food.

The key to healthy skin, the reduction of dermatological problems, results of aging, elimination or even slowing them down is a proper diagnostic. Besides that, understanding the mechanisms that control physiology and metabolism, and the use of preparations based on proper, effective substances. Knowing the mechanisms and causes of skin problems enables the selection of appropriate, biologically active ingredients that inhibit their development and, consequently, improve the condition of the skin. These ingredients can be included in both cosmetic preparations, dietary and functional food supplements.

\section{DIETARY SUPPLEMENTS}

Between food, nutrition and human health there are strict dependencies [1, 2]. In addition to a proper diet, which is essential in maintaining good health and significantly supporting the correct functioning of individual organs, including the skin, dietary supplementation and the consumption of the so-called functional food is needed. This is particularly important due to frequent cases of lack of appropriate nutrients, including, micro and macro elements in the basic diet of many people who lead an unsuitable lifestyle, or are in certain age groups.

Products other than classic food are divided into many subgroups depending on the composition and purpose, like: food products for particular nutritional purposes, functional food, nutricosmetics and supplements, including supplements supporting slimming, proper vision process, influencing motor organs, concentration, delaying the aging processes, supplements for athletes and many others [3, 4]. Preparations influencing the condition of the skin, hair and nails are also a significant group [5].

In turn, the development of the cosmetics industry currently involves not only modern preparations, techniques or cosmetic treatments but also the creation of completely new, innovative product categories in terms of form, use and origin of preparations. The following definitions are commonly used today: dermocosmetics, cosmeceuticals, biocosmetics and nutricosmetics [6]. Consumers identify this type of products as ones of special purpose or origin, properly balanced in terms of their qualitative and quantitative composition, properly produced, labeled and packaged.

Studies show that the diet of many people is inappropriate, and the typical nutrition of an average consumer does not fully cover the body's needs for vitamins and minerals, which is also reflected in the condition of the skin [7]. Therefore, it seems that the use of appropriate dietary supplements and the consumption of functional food is not only beneficial, but in many cases even mandatory. The market of dietary supplements is huge and many people regularly and often excessively use this type of preparations $[8,9]$. This applies to both ill people, including those with skin problems, who want to support or supplement therapy with the use of drugs or follow a dietitian's recommendation, but also, to healthy people who independently supplement their daily care with cosmetic preparations, taking various, often very diverse in terms of composition and action preparations [10].

According to the dietitians' recommendations, the selection of an appropriate diet and its composition should take into account the properly diagnosed needs. For this reason, cooperation between dermatologists, cosmetologists and nutritionists is needed. The basic role of dermatologists is, first of all, to make an appropriate diagnosis, to recommend pharmacological treatment. Cosmetologists can help with proper care, while the role of nutritionists is, taking into account both the diagnosis, the prescribed drugs, cosmetic preparations used in beauty salons and in-home care, to supplement the treatment process with products containing the necessary and missing nutrients. The ingredients can be delivered to the body in the form of supplements or eaten in the form of functional foods. Supplementation during cosmetic procedures increases the effectiveness of treatments and therapies and in the hands of an experienced dietitian and cosmetologist, it is a tool for effective work with the client.

\section{NUTRICOSMETICS}

Despite the emergence of more and more effective forms of cosmetics (like nano-preparations, containing special carriers: liposomes, sphingosomes, microcapsules, molecular complexes), it should be remembered that the primary role of the skin is protection against the ingress of substances from the outside. As a result, many biologically active ingredients found in various, even the most complex preparations applied directly to the skin have relatively poor bioavailability.

Nutricosmetics can complement the action of valuable ingredients of cosmetics by the effective delivery of many biologically active substances and together they may positively influence the condition of the skin, hair, or nails. According to one of the definitions, nutricosmetics are dietary supplements that provide a concentrated form of a particular bioactive ingredient from food, administered in a form other than food, used to improve health, in doses that exceed those that can be obtained from normal food [11]. Dietary supplements, on the other hand, are defined as products 
that are a source of concentrated nutrients and other components with a physiological effect [12]. Undoubtedly, taking into account the above definitions, it can be considered that nutricosmetics belong to dietary supplements. They contain nutrients with biological activity and properties, which can influence the physiological processes in the skin.

Both dietary supplements and nutricosmetics contain the same or similarly-acting substances that can be found in cosmetics but are delivered to the body through the alimentary tract. After oral administration, their task is to support the proper functioning of the skin and its appendages, positively influencing their appearance and general condition. This is due to the fact that the compounds present in such preparations, beneficial to health and supports the maintenance of the skin in good shape, may, for example, be more stable in the gastrointestinal tract. This results in much better absorption from the digestive tube., Due to the above, the main problem of the effective action of cosmetic preparations containing biologically active ingredients is their poor bioavailability when applied directly to the skin.

The most common ingredients of nutricosmetics are: vitamins A, E, C B vitamins, antioxidants, peptides, lipids, macro- and microelements (e.g. zinc and silicon), amino acids (e.g. L-arginine, taurine, cysteine, cystine, methionine, tryptophan), enzymes (e.g. lactase, papain), prebiotics and probiotics (e.g. inulin, bacterial cultures, yeast), essential fatty acids (e.g. $\gamma$-linolenic acid, eicosapentaenoic acid (EPA) and docosahexaenoic acid (DHA)) and others [13]. As a separate group of preparations, very popular among consumers, are nutricosmetics containing substances of plant origin (e.g. catechins, polyphenols, flavonoids (especially rutin, quercetin, kaempferol)), vegetable oils and other ingredients of plant origin (e.g. borage seed oil (Borago officinalis), aloe (Aloe Vera), green tea extract (Camellia sinensis), guarana extract (Paullinia cupana) and others [14] These extracts contain natural antioxidants, substances with anti-inflammatory, smoothing, soothing and sealing properties. $[15,16]$. These components, being able to react at the molecular level, are active towards receptors and act, for example, as enzymes (inhibitors, catalysts), antioxidants, growth factors (hormones) can regulate the biochemical processes taking place in the skin. They may influence the metabolism of cells and stimulate them to a specific reaction, resulting in an improvement of the skin appearance, making the skin more elastic, firming and improving its hydration [17].

\section{FUNCTIONAL FOOD}

There are many studies on the evaluation of the effect of diet on certain skin diseases $[18,19]$. It has been proven that the inflammatory processes in the skin are suppressed and its condition is improved by giving $3 \mathrm{~g}$ a day of vegeta- ble oil containing linolenic acid to children aged 2-4 years old, suffering from atopic dermatitis (AD). Such result was explained by the gradual change and supplementation of the lipid composition of cell membranes. The improvement occurred after four weeks of supplementation [20]. Taking into account the above study, it can be assumed that the use of cosmetics in the form of, for example, specially designed creams, could support the therapeutic process and accelerate the achievement of satisfactory aesthetic effects. This would be related to the fact that the protective skin barrier formed by the layer of lipids and keratinocytes responsible for maintaining proper skin hydration would have a greater chance of appropriate regeneration as a result of the formation of epidermal lipid complexes, consisting mainly of ceramides, free fatty acids, sterols, and also phospholipids and squalene [21-23].

The demand for high nutritional food with health-promoting value causes that more and more preparations are appearing on the market. These kinds of products are supposed to positively affect selected body functions, regulate and support physiological and metabolic processes, including those involving the skin. According to the definition in the final document of the EU Functional Food Science in Europe FUFOSE research program, food can be considered functional if it is proven to have a beneficial effect on one or more body functions over the nutritional effect, which is to improve health and well-being and/or reduce disease risk [24]. Functional foods must resemble conventional foods in form, and exhibit beneficial effects in amounts expected to be a normally consumed diet. Importantly, they are not tablets or capsules, but part of a healthy diet, which is expected to improve health. Another commonly known definition, important as it indicate the key role of biologically active compounds in it, says that food has functional properties only when, in addition to the normal nutritional value, it contains bioactive substances that affect the functioning of the body by blocking or delaying the development of certain diseases and/or improving its overall functioning.

Taking into account the comprehensive approach to the process of supporting skin care, including problematic skin and eliminating imperfections, the possibility of using dedicated cosmetic preparations and consuming functional foods at the same time seems very interesting and may bring the desired results.

The use of the preparations described above could go hand in hand with the appropriate cosmetic diagnostics and thorough assessment of the skin condition, selection of the appropriate cosmetic products, procedures, preceded by an appropriate cosmetic diagnosis. The comprehensive selection of products, whether a cosmetic, a dietary supplement or a functional product, would base on the choice of the appropriate set of biologically active substances. Due to their properties, they would be included in the selected 
type of preparation. In terms of substances added to food, these would be compounds added both in technological processes (production and processing) and already contained in raw materials for food production.

\section{COSMETICS AND SUPPLEMENTS}

The attempts to design this type of food products, as well as preliminary assessment of their composition, properties, functionality and usefulness, the development of protocols for their use together with appropriately selected cosmetic preparations, are the authors' own research interest. The undergoing studies allowed to notice that supporting the skin care process, due to properly selected composition (both in terms of quality and quantity) can bring the expected results in terms of improving both the appearance of the skin and its condition in case of dermatological problems or even certain diseases

One of the substances, present in preparations of various types, is vitamin A, which is actually a group of organic chemical compounds including retinol (an alcoholic form of vitamin A), retinal (aldehyde form), retinoic acid (acid form), derivatives retinol esters (palmitate and acetate). Retinol and vitamin A derivatives show a variety of different functions in the body, but in the skin, the most important role is related to the proper functioning of the epidermis [25]. They influence growth factors and the processes of protein synthesis, cell metabolism, and cell division. They lead to the improvement of the structure of the stratum corneum, enhancement of the protective function of the epidermis, and reduction of the transepidermal water loss (TEWL) [26]. Vitamin A deficiency causes increased follicular keratosis in the skin, which is often accompanied by generalized skin dryness, brittleness, and hair thinning [27]. Retinoids regulate the processes of keratinization and differentiation of keratinocytes, reduce adhesion and facilitate exfoliation of corneocytes, stimulate collagen synthesis and angiogenesis. They also reduce inflammation by inhibiting the lipoxygenase-dependent transformation of arachidonic acid [28, 29]. The use of retinoids in numerous skin problems, such as: atopic dermatitis, psoriasis, acne, and acne-like conditions, photoaging, keratosis disorders, warts, ulcerations, furunculosis, epidermal precancerous conditions, malignant melanoma, promyelocytic leukemia, lichen planus, scleroderma and atrophic leukemia, condylomas, red follicle dandruff, follicular keratosis, common and bullous ichthyosis, hand and foot keratosis is confirmed in scientific publications [30]. The efficiency of absorption of $\beta$-carotene, mainly present in carrots, broccoli, spinach, palm oil, eggplant, is very diverse and is less than $5 \%$ [31]. On the other hand, $\beta$ carotene administered as a dietary supplement can be absorbed by as much as $70 \%$.
For these reasons, cosmetics containing vitamin A are commonly used for multi-directional skin care, especially dry and aging skin. There are numerous studies confirming the effectiveness of the topical application of retinoids, eg tretinoin and isotretinoin, in alleviating the signs of skin aging [32-38]. The use of cosmetic preparations with vitamin A resulted in shallowing of furrows and wrinkles, as well as lightening of lentil spots and discoloration, increased collagen synthesis, and increased angiogenesis [33]. The combination of vitamin A and vitamin $\mathrm{E}$ in one preparation also shows a beneficial effect [38].

Field horsetail (Equisetum arvense), which has antibacterial, and is known due to its remineralizing and regenerating properties, should be mentioned among other raw materials found in cosmetic preparations, dietary supplements, and functional food. It is a rich source of flavonoids, potassium, and silicon, which are necessary for the proper functioning of rapidly growing tissues like the skin, hair, and nails. Silicon is essential in the processes of collagen biosynthesis - the basic component of connective tissue and its deficiency causes graying and brittleness of hair, nails and reduced resistance to mycoses and bacterial infections. For this reason, silicon is a common ingredient used in the production of many supplements of this type [39, 40].

Aloe vera (Aloe vera) is very popular among many cosmetics (creams, gels), used in the treatment of various diseases, including dermatoses, but also as a dietary supplement. Clinical studies have shown that aloe gel, obtained from the leaf flesh and used internally, significantly reduces wrinkles, increases skin elasticity and the production of procollagen [41]. The use of aloe vera extracts helps to maintain proper skin hydration and may be effective in reducing the symptom of dry skin [42].

\section{SUMMARY}

The growing demand and interest in new cosmetic forms, food products, dietary supplements, and functional food, both among consumers and producers, indicates the need for continuous, ongoing research on aspects related to this issue and conducting additional scientific research in the field of their proper and effective use. It seems particularly important to pay attention to a holistic, broad approach to skin care, in terms of dermatology, cosmetics, and diet. The diet of many people is inappropriate, and the typical diet of an average consumer does not fully cover the body's needs for nutrients important for proper functioning. It is worth notify the comprehensive approach to the process of supplying the body with the necessary nutrients, taking into account both the appropriate diet, supplemented with additional preparations and cosmetic products, as well as the cooperation of doctors, nutritionists, and cosmetologists necessary to achieve the desired results. 


\section{REFERENCES / LITERATURA}

1. Gardocka-Jałowiec A, Stańczyk P, Szalonka K. Wpływ żywienia i żywności na stan zdrowia w świetle badań, in: Szalonka K, Nowak W, eds. Zdrowie i style życia. Determinanty dtugości życia. Wrocław: E-Wydawnic two. Prawnicza i Ekonomiczna Biblioteka Cyfrowa. Wydział Prawa, Administracji i Ekonomii Uniwersytetu Wrocławskiego; 2020:95-113. https://doi.org/10.34616/23.20.112

2. Ciborowska H, Rudnicka A. Dietetyka. Żywienie zdrowego i chorego cztowieka. Warszawa: Wyd. PZWL; 2020.

3. Bojarowicz H, Dźwigulska P. Suplementy diety. Część I. Wybrane składniki suplementów diety oraz ich przeznaczenie. Hygeia Public Health. 2012;47(4):427-432.

4. Brzozowska A, Roszkowski W, Pietruszka B, et al. Witaminy i składniki mineralne jako suplementy diety. Żywn Nauk Technol Jakość. 2005;4(45):5-16.

5. Krasnowska G, Sikora T. Suplementy diety a bezpieczeństwo konsumenta. Żywn Nauk Technol Jakość. 2011;4(77):5-23.

6. Grzyb S. Nowe kategorie kosmetyczne - moda czy potrzeba. Art of Beauty. 2018;3:6-8.

7. Dudek K, Borysławski K. Wpływ diety na parametry skóry u kobiet po 45. roku życia. Kosmetologia Estetyczna. 2016;6(5):627-630.

8. Maienschein V. Nastolatki jako grupa celowa, trendy w kosmetykach dla generacji Internetu. SOFW-Journal Wydanie Polskie. 2008;1:27-29.

9. Gollnick H, Cunliffe W, Berson D, et al. Management of acne: a report from a global Alliance to improve outcomes in acne. J Am Acad Dermatol. 2003;49:1-37.

10.Stoś K, Szponar L, Bogusz W, et al. Suplementy diety jako źródło składników o działaniu odżywczym i innym fizjologicznym. Żyw Człow Metabol. 2007;34:1036-1040.

11. Ciepłucha K. Nutraceutyki. Panacea. 2004;2(7):11-13.

12.Jarosz M. Suplementy diety a zdrowie. Warszawa: Wyd. PZWL; 2008.

13. Szyszkowska B, Lepecka-Klusek C, Kozłowicz K, et al. The influence of selected ingredients of dietary supplements on skin condition. Post Dermatol i Alergol. 2014;31(3):174-181.

14. Schlegel-Zawadzka M, Barteczko M. Ocena stosowania suplementów diety pochodzenia naturalnego w celach prozdrowotnych przez osoby dorosłe. Żywn Nauk Technol Jakość. 2009;4(65):375-387.

15. Palmer DM, Silverman JK. Oxidative damage, skin aging, antioxidants and a novel antioxidant rating system. J Drug Dermatol. 2010;9:11-15.

16. Gupta VK, Sharma SK. Plants as natural antioxidants. Natural Prod Radiance. 2006;5(4):326.

17. Wyszkowska-Kolatko, M, Koczurkiewicz-Adamczyk P, Wójcik-Pszczoła K, Pękala E. Rośliny lecznicze w terapii chorób skóry. Postępy Fitoterapii. 2015;3:184-192.

18. Lee T, Hoover R, Williams J, et al. Effect of dietary enrichment with eicosapentaenoic and docosahexaenoic acids on in vitro neutrophil and monocyte leukotriene generation and neutrophil function. $N E n g l$ JMed. 1985;312:1217-1224.

19. Rosińska A, Niestrata Z, Cichy W. Wpływ składników pokarmowych na stan fizykochemiczny skóry. Przeg Dermatol. 2006;3:325-332.

20. Steward J, Morse P, Moss M, et al. Treatment of severe and moderately severe atopic dermatitis with evening primrose oil (Epogam): a multicentre study. J Nutr Med. 1991;2:9-15.

21. Bem B. Rola wyższych kwasów tłuszczowych w fizjologii skóry. Pol J Cosmetol. 2003;2:93-101.
22. Szmurło A. Rola lipidów naskórkowych w prawidłowym funkcjonowaniu bariery naskórkowej. Dermatologica. 2006;7:53-56.

23.Van Gool CJ, Zeegers MP, Thijs C. Epidemiology and Health Services Research. Oral essential fatty acid supplementation in atopic dermatitis-a meta-analysis of placebo-controlled trials. $\mathrm{Br} J$ Dermatol. 2004;150:728-740.

24. Jeznach M, ed. Stan i perspektywy rozwoju rynku żywności funkcjonalnej. Warszawa: SGGW; 2003.

25. Miller SJ. Nutritional deficiency and the skin. J Am Acad Dermatol. 1982;21:1-30.

26. Sorg O, Kuenzli S, Kaya G, at al. Proposed mechanisms of action for retinoid derivatives in the treatment of skin aging. $J$ Cosmetic Dermatol. 2005;4:237-244.

27. Bolognia JL, Jorizzo JL, Rapini R. Dermatology. Second Edition. London: Mosby Elsevier; 2008:664-665,1935-1948.

28. Bojarowicz H, Płowiec A. Wpływ witaminy A na kondycję skóry. Probl Hig Epidemiol. 2010;91(3):352-356.

29. Schmitt-Hoffmann AH, Roos B, Sauer J, at al. Pharmacokinetics, efficacy and safety of alitretinoin in moderate or severe chronic hand egzema. Clin Exp Dermatol. 2011;36(2):29-34.

30. Adamski Z, Kaszuba A. Dermatologia dla kosmetologów. Wrocław: Elsevier Urban \& Partner; 2011.

31. Burns J, Fraser PD, Bramley PM. Identification and quantification of carotenoids, tocopherols and chlorophylls in commonly consumed fruits and vegetables. Phytochemistry. 2003;62:939-947.

32. Galus R, Zandecki Ł, Antiszko M, et al. Fotostarzenie się skóry. Pol Merk Lek. 2007;22:580.

33. Gianeti MD, Wagemaker TAL, Seixas VC, et al. The use of nanotechnology in cosmetic formulations: the influence of vehicle in the vitamin A. Skin Penetration Current Nanoscience. 2012;8:526-534.

34. Gianeti MD, Gaspar LR, Camargo FB Jr, et al. Benefits of combinations of vitamin A, C and E derivatives in the stability of cosmetic formulations. Molecules. 2012;17:2219-30.

35. Ellis CN, Weiss JS, Hamilton TA, et al. Sustained improvement with prolonged topical tretinoin, retinoic acid for photoaged skin. $\mathrm{J} \mathrm{Am}$ Acad Dermatol. 1990;23(4 Pt 1):629-37.

36. Lever L, Kumar P, Marks R. Topical retinoic acid for treatment of solar damage. Br J Dermatol. 1990;122:91-98.

37. Olsen EA, Katz HI, Levine N, et al. Tretinoin emollient cream for photodamaged skin: results of 48-week, multicenter, double-blind studies. J Am Acad Dermatol. 1997;37(Pt 1):217-26.

38. Kuczyński S. Zastosowanie retinoidów w terapii starzejącej się skóry. Medycyna Estetyczna i Przeciwstarzeniowa. 2006;4:161-167.

39. Bojarowicz H, Dźwigulska P. Suplementy diety. Część II. Wybrane składniki suplementów diety oraz ich przeznaczenie. Hygeia Public $\mathrm{He}$ alth. 2012;47(4):433-441.

40. Cho S, Lee S, at al. Dietary Aloe Vera Supplementation Improves Facial Wrinkles and Elasticity and It Increasesthe Type I Procollagen Gene Expression in Human Skin in vivo. Ann Dermatol. 2009;21(1):6-11.

41. Dal'Belo SE, Gaspar LR, Maia Campos PM. Moisturizing effect of cosmetic formulations containing Aloe vera extract in different concentrations assessed by skin bioengineering techniques. Skin Res Technol. 2006;12(4):241-246.

42. Potargowicz E, Szerszenowicz E. Polifenole roślinne w kosmetyce. Pol J Cosmetol. 2006;9:70-76. 